\title{
REVISITING LINKAGES BETWEEN STOCK PRICES \\ AND REAL ACTIVITY IN OECD COUNTRIES: \\ DOES FINANCE RESPOND TO CHANGING SITUATION OF ECONOMY?
}

\section{Mercan Hatipoglu*}

\begin{abstract}
The purpose of this study is to investigate whether financial markets contribute to the economy when needed. The quantile regression model and causality in variance tests are applied to monthly data from December 1989 to July 2016 for 19 OECD economies. The results confirm that the response of capital markets to economic growth depends more on the state of the economy than the state of the country's development. Generally, interaction between financial markets and the economy is weak in OECD countries except Japan and Estonia.
\end{abstract}

Keywords: stock market, economic growth, quantile regression

JEL Classification: G10, O11, O47

\section{Introduction}

The firm valuation theory suggests that the stock price depends of the present value of the future dividends of a firm. According to the model, future dividends are assumed to reflect the growth rate of the economy, and investors decrease their expectations about the dividend if they predict economic stagnation in near future (Chen et al., 1986). Correspondingly, the stock price will decrease before the economic activity. Meanwhile, the market interest rate, which is used as the discounting factor to calculate the present value of dividend, reflects the uncertainty of economic outlook. Therefore, raising the discount rate causes a fall in the stock price and possibly economic recession (Pearce, 1983). Keynes (1936) first argued that stock markets generated speculative prices which were not related to the economic performance of firms, but Fama (1990) documented that stock market performance could be used as a proxy variable to predict actual economic activity.

* Mercan Hatipoglu, Cankiri Karatekin University, Cankiri, Turkey (mercanhatipoglu@gmail.com). 
Demirgüç-Kunt and Levine (1996) emphasized the usefulness of the level of stock market development in predicting future economic growth. These studies summarize the leading indicator function of an equity market. In addition, numerous studies have been conducted to theoretically explain why an equity market can prompt economic growth. First, Fischer and Merton (1984) posited that the stock market valuation played a favourable role in reducing the costs of capital and made companies willing to increase the investments. Bencivenga et al. (1996) provided evidence on the advantages of the stock market in a real economy. They concluded that stock markets transformed the financial assets into less risky assets by bringing them liquidity. Therefore, investors quickly set their portfolios by performing transactions, andfirmscaneasily access the capitalmarkets to fund investments through equity issues. Rousseau and Wachtel (2000) asserted that stock markets enabled the funding of current account deficits via portfolio diversification because venture capital and portfolio investments tended to flow on more liquid and organized financial markets. Levine (1991) attested that efficient capital markets permitted small firms to access funds and give them competition opportunities on a world platform. Bekaert and Harvey (1998) paid attention to the relation between financial market integration and economic growth. They postulated that the costs of capital in an integrated market were lower than domestic ones because the investors could easily diversify the risks from international financial assets, so they did not demand excessive risk premiums for the local risk. Wachtel (2001) stressed the role of traded firms in providing information from management to shareholders, which could be helpful for evaluating the company developments. Levine (1997) emphasized that financial markets could ameliorate market frictions, transaction costs and constraints that the economic agents faced. Jovanovic (1990) contended that by curtailing informational asymmetries, financial systems facilitated the monitoring of investment project and resources. Stiglitz and Weiss (1983) noticed the potentially positive effect of corporate governance on shareholders, creditors and managers. Hence, managers exert to maximize the firm value, and increasing the firm performance also has an effect on the growth rates. Although the stock market has many advantages, there is a theoretical disagreement about the role of stock markets in economic growth. For example, Morck et al. (1990) stated that the stock market could retard the economy by generalizing unkind firm takeovers. Shiller (1990) indicated that the deviation of stock prices from their fundamental value originated from irrational exuberance and speculative bubbles. Singh (1999) claimed that the stock market development might not be beneficial for economic growth for several reasons. He noted the short-termism notion, which indicates that investors prefer shortterm financial gain to long-term enterprise. Second, financial markets are used to attract foreign portfolio flow, which makes the economy more vulnerable to capital outflow. Finally, in stock market-oriented economies, one who invents financial engineering will 
be rewarded instead of contributing to industrial production. This study aims to clarify our understanding of the stock market and economic growth nexus in the context of the Organisation for Economic Co-operation and Development (OECD) countries. Information about the effect of finance on the economic growth will affect the priority of policy makers, who would seek a method to reform the financial sector. This paper contributes to the existing literature by analysing the role of the stock market in economic activity by considering the regime of economy, e.g., when the economy is about to have a recession and when the economy grows. The answer to this question has important policy implications because clarifying the role of the stock index in economic growth may lead governments to support developing their financial markets to promote economic growth. Another objective of the paper is to reveal the relationship between financial markets and economic activity by addressing the second moment process. The theoretical background for this link can be attributed to the volatility of actual economic activity, which is a major determinant of stock return volatility as proposed by Schwert (1989).

\section{Literature Review}

A considerable amount of research has been conducted on the effect of the stock market on different economies. A new study of Atje and Jovanovic (1993) accentuated that the role of the volume of transactions in the stock market significantly affected economic growth. Moreover, Demetriades and Hussein (1996) determined the bidirectional causality between financial development and economic growth. Arestis et al. (2001) found that banks contributed to the growth of developed countries more than the stock market. Mauro (2003) reported that the correlation between the stock market and growth tended to increase because of the initial public offerings, regulations and a high market capitalization to GDP. Nieuwerburghe et al. (2006) stated the facility role of the equity market in growth for firms in Belgium during the period 1873-1935. For Asia-Pacific Economic Cooperation (APEC) countries at different stages of development, Tang (2006) concluded that the stock market development enhanced growth only for the developed APEC countries. Furthermore, Cooray (2010) used the argument of Mankiw et al. (1992) and found that the stock market supported growth for a cross section of 35 developing economies. Nourzad (2002) noted that financial deepening contributed to the productive efficiency in both developed and developing countries by using a stochastic production frontier. In contrast, several studies arise from the empirical literature documenting that the effect of stock markets on the economic growth is not statistically significant. For example, Harris (1997) found no evidence that the stock market had explanatory power in growth for less developed and developed countries. The same results were obtained by Ram (1999), who showed no beneficial effect of the financial development on growth using 
data for 95 individual countries. Dawson (2003) stated that the financial development did not spur the growth in transition economies in Central and Eastern Europe. Similarly, the evidence obtained by Handa and Khan (2008) indicates that finance makes no significant contribution to the development of less developed countries. Binswanger (2004) confirmed that the relationship between stock returns and growth output was a breakdown for G-7 countries after 1980. Pilinkus (2010) studied the relationships between stock prices and GDP growth for Lithuania, Estonia, and Latvia and indicated that the stock market indices were more strongly linked to GDP in the long-run. Many papers in the literature have analysed the leading role of the stock market in the economy based on the volatility. Kim and In (2003) used the wavelet analysis to investigate the relationship between financial variables and the industrial production of the USA. Overall, they found that the lead-lag correlation and coherence of financial variables and US industrial production depended on the time scale. Guo (2015) documented that stock markets began to lead the real economy in China after the subprime crisis using a non-uniform weighting crosscorrelation approach. Colombage (2009) advocated a natural relationship among the GDP growth rate, the stock and bond market for 5 developed economies. According to his result, the supply-leading hypothesis is valid for all countries except Canada. Teng et al. (2016) noted that the volatility on ASEAN-5 stock markets significantly affected China's economy using the DCC-MGARCH model. Caporale and Spagnolo (2003) examined that the stock market volatility positively affected the output growth volatility in three industrialized countries. Ahn and Lee (2006) posited that the volatility on the stock market was traced by higher volatility in the real output for several developed countries. Duca (2007) focused on the role of market capitalization in terms of the causality relation between the real economy volatility and the stock market volatility.

\section{Data and Methodology}

The data in the paper are the monthly frequency (calculated using monthly closing prices) stock market and industrial production indices for 19 OECD member countries. The data cover the period from December 1989 to July 2016 and were obtained from the OECD's Main Economic Indicators database. We also classify OECD countries into two groups: developed and emerging markets. The national stock price index and domestic industrial production are selected as the measures for the domestic stock prices and economic activity, respectively. Industrial production is used as the variable that represents the real activity (Binswanger, 2004; Caporale and Spagnolo, 2003). Appendix 1 presents the data period and the time-varying effect of the stock market on the industrial production for each country. The quantile regression technique, which was developed by Koenker and Bassett (1978), is presented as follows: 


$$
\begin{aligned}
& Y=X^{\prime} \beta+\varepsilon, \\
& Q_{y}\left(\frac{\tau}{X}\right)=X^{\prime} \beta(\tau),
\end{aligned}
$$

where $Y$ is the dependent variable, $X$ is a $k \times 1$ vector of independent variables, $\beta$ is an unknown $k \times 1$ vector of coefficients associated with the $\theta^{t h}$ percentile and $Q_{y}(\tau / X)$ is the $\tau^{\text {th }}$ conditional quantile of $Y$, which implies that the reactions of the dependent variable is linear to changes in the independent variable. The quantile regression estimators can be obtained by minimizing the following equation:

$$
\beta=\operatorname{argmin}_{\beta}\left(\sum_{i: y_{i}>x_{i}^{\prime} \beta} \theta\left|y_{i}-x_{i}^{\prime} \beta\right|+\sum_{i: y_{i}<x_{i}^{\prime} \beta}(1-\theta)\left|y_{i}-x_{i}^{\prime} \beta\right|\right) .
$$

The benefit of the quantile regression technique is to examine the relationship between an outcome variable $Y$ (industrial production) and an input variable $X$ (stock market return) in detail. This study is interested in the effects of the stock market on the economy at any specific level using the quantile regression. It also enables us to address the question of whether finance responds to a changing situation of the economy. In this paper, quantiles can be interpreted as states or regimes of the economy. Lower quantiles (e.g., the $5 \%, 10 \%, 25 \%$ quantile) indicate a bad state (recession), and higher quantiles (e.g., the $75 \%, 90 \%, 95 \%$ quantile) indicate a good state or regime. $\beta_{\tau}$ measures the dependence structure between dependent and independent variables in the regression. For example, if the coefficients of the quantiles do not differ from one another, the comovement of dependent and independent variables is said to be constant. However, if the coefficient changes across the quantiles, the dependence structure has a dynamic connection. Therefore, if the coefficients in lowest and highest quantiles are dissimilar, the dependence structure displays symmetric features (Naifar, 2016). To assess the volatility spillover between the real economy and the financial market, we use the causality in the variance test developed by Hafner and Herwartz (2006). The main intuition of the test is based on estimating the univariate GARCH models:

$$
h_{i, t}=\omega+a_{i} \varepsilon_{i, t-1}^{2}+\beta_{\mathrm{i}}+h_{i, t-1},
$$

where $i=1,2 ; \varepsilon_{i, t}$, is defined over the $(\Omega, \mathrm{F}, \mathrm{P})$ probability space. Let $j \neq i$. The null hypothesis of non-causality in variance between two return series is described as follows:

$$
h_{0}=\operatorname{Var}\left(\varepsilon_{i, t} \mid F_{t-1}^{(j)}\right)=\operatorname{Var}\left(\varepsilon_{i, t} \mid F_{t-1}\right) j=1, \ldots, N, j \neq i,
$$

where $F_{t}^{(j)}=F_{t} \mid \sigma\left(\varepsilon_{j t}, \tau \leq t\right) ; \varepsilon_{i, t}$ is the residual from the GARCH model. Hence, we define the standardized residuals as $z_{t}$ and the process 


$$
g_{t}=1+\xi_{i, j}^{\prime} \pi, \varepsilon_{i, t}=z_{i, t} \sqrt{h_{i, t}} g_{t} \text { and } \xi_{j, t}=\left(\varepsilon_{j, t-1}^{2} h_{j, t-1}\right)^{\prime} .
$$

Thus, a sufficient condition to test the causality is whether $\pi$ is equal to zero and there is no spillover from $j$ to $i$.

\section{Empirical Findings}

Table 1 presents the descriptive statistics for the monthly percentage continuously compounded returns of stock indices and industrial production, which is calculated by using the log differences of both industrial production and stock prices. Augmented Dickey-Fuller statistics show the rejection of unit roots in each series at the $1 \%$ level for all countries. The value of the JB test indicates that the variables exhibit a non-normal distribution. This fact is supported by a relatively large kurtosis value, which implies that the underlying data are leptokurtic. The asymmetric behaviour in the stock return series can be observed from the skewness coefficients. We observe that developed stock markets have a negative skewness. We can interpret that the equity markets in developed countries are strongly characterized by more likely bad surprises. These results are valid for emerging markets with the exception of Poland, Greece, Slovak Republic, Slovenia and Brazil. The most common measure of risk in finance is the standard deviation. The standard deviation varies from $3.50 \%$ for the USA to $5.05 \%$ for Italy on the developed stock markets and from $4.02 \%$ for Belgium to $15.9 \%$ for Brazil. This value suggests that including stocks from emerging markets will increase the portfolio risk. The quantile regression provides a more efficient parameter when the data exhibit non-normal distributions. The Jarque-Berra statistics confirm that the null hypothesis of normality is rejected for both variables (industrial production and stock return) in all countries. In Table 2, the variability of industrial production is considerably higher in emerging countries than in developed countries. 


\begin{tabular}{l|c|c|c|c|c|c}
\hline \multicolumn{7}{c}{ Developed markets } \\
\hline Mean & Std.dev & Skewness & Kurtosis & JB & ADF \\
\hline Japan & -0.002 & 0.053 & -0.338 & 4.351 & $30.357^{* * *}$ & $-13.540^{* * *}$ \\
\hline France & 0.005 & 0.035 & -1.519 & 11.513 & $1,086.000^{* * *}$ & $-13.620^{* * *}$ \\
\hline UK & 0.002 & 0.046 & -0.887 & 4.866 & $87.911^{* * *}$ & $-13.390^{* * *}$ \\
\hline Germany & 0.003 & 0.036 & -0.950 & 6.397 & $202.350^{* * *}$ & $14.990^{* * *}$ \\
\hline Italy & 0.003 & 0.048 & -1.039 & 5.610 & $147.990^{* * *}$ & $-13.310^{* * *}$ \\
\hline
\end{tabular}

\section{Emerging markets}

\begin{tabular}{l|c|c|c|c|c|c}
\hline & Mean & Std.dev & Skewness & Kurtosis & JB & ADF \\
\hline Poland & 0.012 & 0.088 & 0.518 & 10.752 & $769.800^{* * *}$ & $-11.730^{* * *}$ \\
\hline Turkey & 0.002 & 0.062 & -0.400 & 4.435 & $35.917^{* * *}$ & $-33.370^{* * *}$ \\
\hline Belgium & 0.003 & 0.042 & -1.132 & 8.225 & $433.120^{* * *}$ & $-13.430^{* * *}$ \\
\hline Czech Republic & -0.000 & 0.061 & -0.575 & 6.320 & $138.930^{* * *}$ & $-11.210^{* * *}$ \\
\hline Hungary & 0.010 & 0.072 & -0.367 & 8.347 & $371.510^{* * *}$ & $-11.990^{* * *}$ \\
\hline Estonia & 0.005 & 0.071 & -1.303 & 8.542 & $347.020^{* * *}$ & $-9.860^{* * *}$ \\
\hline Greece & 0.000 & 0.085 & 0.153 & 3.670 & $7.220^{* * *}$ & $12.450^{* * *}$ \\
\hline Slovak Republic & 0.004 & 0.080 & 5.115 & 62.640 & $418.430^{* * *}$ & $-11.530^{* * *}$ \\
\hline Slovenia & 0.002 & 0.060 & 0.179 & 5.638 & $78.280^{* * *}$ & $-6.701^{* * *}$ \\
\hline Brazil & 0.049 & 0.159 & 0.957 & 8.821 & $497.660^{* * *}$ & $-5.210^{* * *}$ \\
\hline India & 0.007 & 0.061 & -0.044 & 4.607 & $37.760^{* * *}$ & $-12.880^{* * *}$ \\
\hline Russia & 0.013 & 0.103 & -0.470 & 8.770 & $322.080^{* * *}$ & $-10.910^{* * *}$ \\
\hline
\end{tabular}

Notes: the lag length is given in parentheses. ${ }^{* * *},{ }^{* *}$, and ${ }^{*}$ indicate the significance at $1 \%, 5 \%$ and $10 \%$, respectively. For the $A D F$ test, maxlag $=14$; automatic is based on sic.

Author's calculations. 
Table 2: Descriptive statistics of the industrial productions

\section{Developed markets}

\begin{tabular}{l|c|c|c|c|c|c}
\hline & Mean & Std.dev & Skewness & Kurtosis & JB & ADF \\
\hline Japan & -0.001 & 0.028 & -2.820 & 23.167 & $5,831.11^{* * *}$ & $-16.950^{* * *}$ \\
\hline USA & 0.001 & 0.006 & -1.773 & 12.654 & $1,406.11^{* * *}$ & $-4.730^{* * *}$ \\
\hline France & -0.000 & 0.013 & 0.034 & 4.074 & $15.360^{* * *}$ & $-9.590^{* * *}$ \\
\hline UK & 0.000 & 0.008 & -0.875 & 6.589 & $211.930^{* * *}$ & $-21.610^{* * *}$ \\
\hline Germany & 0.001 & 0.014 & -0.501 & 5.821 & $119.230^{* * *}$ & $-7.650^{* * *}$ \\
\hline Spain & 0.000 & 0.015 & 0.285 & 5.297 & $74.488^{* * *}$ & $-4.510^{* * *}$ \\
\hline Italy & 0.000 & 0.012 & -0.403 & 4.041 & $23.100^{* * *}$ & $-7.840^{* * *}$ \\
\hline
\end{tabular}

\section{Emerging markets}

\begin{tabular}{l|c|c|c|c|c|c}
\hline & Mean & Std.dev & Skewness & Kurtosis & JB & ADF \\
\hline Poland & 0.004 & 0.021 & -0.219 & 5.015 & $53.550^{* * *}$ & $-24.490^{* * *}$ \\
\hline Turkey & 0.026 & 0.113 & 0.412 & 5.207 & $73.790^{* * *}$ & $-14.240^{* * *}$ \\
\hline Belgium & 0.001 & 0.023 & -0.083 & 6.818 & $194.200^{* * *}$ & $-17.480^{* * *}$ \\
\hline Czech Republic & 0.002 & 0.022 & -0.412 & 5.750 & $92.740^{* * *}$ & $-21.850^{* * *}$ \\
\hline Hungary & 0.003 & 0.027 & -0.753 & 6.427 & $178.710^{* * *}$ & $-23.900^{* * *}$ \\
\hline Estonia & 0.003 & 0.028 & -0.191 & 4.047 & $11.500^{* * *}$ & $-17.210^{* * *}$ \\
\hline Greece & -0.000 & 0.029 & 0.522 & 9.968 & $660.050^{* * *}$ & $-15.090^{* * *}$ \\
\hline Slovak Republic & 0.003 & 0.032 & -0.951 & 7.950 & $321.300^{* * *}$ & $-21.150^{* * *}$ \\
\hline Slovenia & 0.001 & 0.026 & -0.877 & 8.723 & $395.230^{* * *}$ & $-22.710^{* * *}$ \\
\hline Brazil & 0.000 & 0.029 & -1.687 & 37.510 & $1,559.110^{* * *}$ & $-21.000^{* * *}$ \\
\hline India & 0.004 & 0.019 & 0.369 & 6.461 & $139.340^{* * *}$ & $-24.930^{* * *}$ \\
\hline Russia & 0.001 & 0.022 & 0.442 & 18.350 & $227.400^{* * *}$ & $-17.670^{* * *}$ \\
\hline
\end{tabular}

Notes: ${ }^{* * *},{ }^{* *}$, and ${ }^{*}$ indicate the significance at $1 \%, 5 \%$ and $10 \%$, respectively.

Author's calculations. 
Developed markets

\begin{tabular}{l|c|c|c|c|c|c|c}
\hline & $\boldsymbol{\beta}_{0.05}$ & $\boldsymbol{\beta}_{0.10}$ & $\boldsymbol{\beta}_{0.25}$ & $\boldsymbol{\beta}_{0.50}$ & $\boldsymbol{\beta}_{0.75}$ & $\boldsymbol{\beta}_{0.90}$ & $\boldsymbol{\beta}_{0.95}$ \\
\hline Japan & $0.141^{*}$ & $0.130^{* *}$ & $0.065^{* * *}$ & $0.063^{* *}$ & $0.051^{* *}$ & 0.020 & $0.038^{* *}$ \\
\hline USA & $-0.017^{* *}$ & -0.015 & -0.005 & 0.021 & $0.037^{* * *}$ & $0.045^{* * *}$ & $0.045^{* * *}$ \\
\hline France & 0.003 & 0.003 & 0.012 & 0.014 & $0.031^{*}$ & $0.035^{* * *}$ & $0.035^{* * *}$ \\
\hline UK & -0.012 & 0.012 & 0.000 & 0.023 & $0.025^{* *}$ & $0.034^{* * *}$ & $0.037^{* * *}$ \\
\hline Germany & $0.114^{* *}$ & 0.297 & $0.045^{* *}$ & 0.016 & 0.022 & 0.027 & -0.015 \\
\hline Spain & $0.062^{* * *}$ & 0.041 & -0.011 & 0.029 & 0.030 & 0.013 & 0.034 \\
\hline Italy & $0.111^{* * *}$ & $0.036^{*}$ & $0.040^{*}$ & $0.043^{* * *}$ & 0.016 & 0.001 & -0.017 \\
\hline
\end{tabular}

\section{Emerging markets}

\begin{tabular}{l|c|c|c|c|c|c|c}
\hline & $\boldsymbol{\beta}_{0.05}$ & $\boldsymbol{\beta}_{0.10}$ & $\boldsymbol{\beta}_{0.25}$ & $\boldsymbol{\beta}_{0.50}$ & $\boldsymbol{\beta}_{0.75}$ & $\boldsymbol{\beta}_{0.90}$ & $\boldsymbol{\beta}_{0.95}$ \\
\hline Poland & 0.012 & 0.034 & 0.028 & 0.019 & $0.024^{* *}$ & $0.028^{* * *}$ & 0.025 \\
\hline Turkey & 0.178 & -0.103 & 0.008 & 0.068 & 0.095 & 0.246 & $0.431^{* * *}$ \\
\hline Belgium & -0.036 & 0.007 & $0.062^{* * *}$ & 0.031 & $0.092^{* *}$ & 0.081 & -0.002 \\
\hline Czech Republic & 0.029 & $0.045^{* *}$ & 0.031 & 0.039 & $0.052^{* *}$ & 0.014 & 0.007 \\
\hline Hungary & -0.035 & $0.075^{* * *}$ & 0.035 & 0.006 & -0.011 & -0.003 & 0.009 \\
\hline Estonia & $0.144^{* *}$ & $0.111^{* *}$ & 0.051 & $0.071^{* *}$ & $0.085^{* * *}$ & $0.142^{* * *}$ & $0.171^{* * *}$ \\
\hline Greece & 0.027 & 0.043 & 0.003 & -0.009 & -0.019 & -0.027 & 0.046 \\
\hline Slovak Republic & $0.080^{* * *}$ & 0.014 & 0.023 & 0.022 & 0.002 & 0.000 & 0.051 \\
\hline Slovenia & $0.012^{* * *}$ & -0.056 & 0.003 & -0.022 & -0.026 & -0.045 & -0.113 \\
\hline Brazil & $-0.048^{* *}$ & -0.013 & -0.006 & -0.005 & 0.014 & 0.010 & 0.024 \\
\hline India & 0.031 & $0.040^{* *}$ & 0.030 & $0.040^{* *}$ & 0.026 & 0.034 & 0.043 \\
\hline Russia & -0.015 & 0.010 & 0.013 & 0.009 & 0.010 & 0.022 & $0.039^{*}$ \\
\hline
\end{tabular}

Notes: ${ }^{* *},{ }^{* *}$, and ${ }^{*}$ indicate the significance at $1 \%, 5 \%$ and $10 \%$, respectively.

Source: Author's calculations. 
Table 4: Causality in variance results

\begin{tabular}{|c|c|c|c|c|}
\hline \multirow[b]{2}{*}{ Developed markets } & \multicolumn{2}{|c|}{$\begin{array}{c}\text { Null hypothesis } \\
\text { Stock market } \neq>\text { industrial prod }\end{array}$} & \multicolumn{2}{|c|}{$\begin{array}{l}\text { Null hypothesis } \\
\text { industrial prod } \neq>\text { Stock marke }\end{array}$} \\
\hline & LM statistic & $p$-value & LM statistic & $p$-value \\
\hline Japan & 0.905 & 0.637 & 2.205 & 0.332 \\
\hline USA & 7.816 & 0.020 & 107.370 & 0.000 \\
\hline France & 30.586 & 0.005 & 9.531 & 0.008 \\
\hline UK & 5.880 & 0.052 & 5.738 & 0.056 \\
\hline Germany & 12.308 & 0.002 & 3.496 & 0.174 \\
\hline Spain & 2.564 & 0.277 & 7.321 & 0.025 \\
\hline Italy & 4.290 & 0.117 & 8.658 & 0.013 \\
\hline Emerging markets & LM statistic & $p$-value & LM statistic & $p$-value \\
\hline Poland & 2.375 & 0.304 & 0.933 & 0.626 \\
\hline Turkey & 10.709 & 0.004 & 2.905 & 0.228 \\
\hline Belgium & 10.094 & 0.006 & 2.310 & 0.315 \\
\hline Czech Republic & 3.557 & 0.168 & 1.420 & 0.491 \\
\hline Hungary & 3.069 & 0.215 & 3.081 & 0.214 \\
\hline Estonia & 4.303 & 0.116 & 0.642 & 0.725 \\
\hline Greece & 7.652 & 0.021 & 1.392 & 0.498 \\
\hline Slovak Republic & 0.806 & 0.650 & 7.161 & 0.027 \\
\hline Slovenia & 17.911 & 0.000 & 0.011 & 0.994 \\
\hline Brazil & 4.648 & 0.097 & 1.949 & 0.377 \\
\hline India & 3.053 & 0.217 & 2.644 & 0.266 \\
\hline Russia & 21.133 & 0.000 & 2.580 & 0.004 \\
\hline
\end{tabular}

Notes: ${ }^{* * *},{ }^{* *}$, and ${ }^{*}$ indicate significance at $1 \%, 5 \%$ and $10 \%$, respectively.

Source: Author's calculations.

Table 3 shows the coefficients of the stock market for industrial production in different conditions for OECD member countries. In Japan, the coefficients are positive and significant throughout the distribution except the $0.90^{\text {th }}$, which implies that the stock market and industrial production exhibit higher co-movement. Thus, Japanese real economy takes advantage of the equity market in every condition. Meanwhile, the coefficients for France and the UK indicate that industrial production in these countries is affected by stock return 
changes only when the industrial production reaches a saturation point. The identical condition is completely reversely valid for Spain, Italy and Germany, which implies that only the deepest level of real economy is affected by stock return. The difference in the sign of the US coefficients in the lowest and highest quantiles emphasizes that the relationships between stock price and real economic activity are dramatically asymmetric. As Table 3 shows, the lower quantiles of the relationship between stock return and industrial production is significant for Slovak Republic, Slovenia, Brazil and Hungary. Thus, industrial production is affected by stock prices, particularly in the low distribution of the real economy. Conversely, the coefficients for Poland, Turkey and Russia are inclined to be meaningful when the industrial production increases to the peak $\left(0.75^{\text {th }}, 0.90^{\text {th }}\right.$ or $\left.0.95^{\text {th }}\right)$. These findings indicate that stock return affects economic growth when industrial production offers a better performance. The median and nearly close estimators of the median are significant for India, Belgium and the Czech Republic. Hence, financial markets play an effective role in the economic development during normal times on such emerging markets. Obviously, no coefficients of Greece are meaningful in all the quantiles, which indicates that the links between stock prices and industrial production are ruptured. This issue induces the leading indicator function of stock market losses in Greece. A significant relationship between stock return and production is found for Estonia in all the quantiles except 0.50 . This dependence may be explained by the fact that firms enjoy easy access to fund themselves from equity issues in Estonia.

The results (Table 4) show that the real economy and financial market are more closely linked in developed countries than emerging markets. The USA, France and the UK have bidirectional causality variance relationships, whereas only Russia has this relation among the emerging markets. However, Germany, Turkey, Belgium, Greece, Slovenia and Brazil have a unidirectional volatility spillover effect from the stock market to industrial production. This effect may originate from consumers' and investors' unfavourable expectation ("something has gone wrong") related to stock return volatility. Because heightened volatility is interpreted as uncertainty about future economic conditions, the increased price variability demolishes the consumer confidence and causes a postponement in investment decisions. Some policy measures in favour of reducing volatility have been recommended by Kupiec (1991). These reforms cover the circuit breakers, who mean to halt trading activity for periods when the stock market prices are below a predetermined limit or the prices exhibit enormous fluctuations. To reduce speculative information arrivals, a practice known as sunshine trading, which enables institutional investment companies to declare the size of their trading orders to the other market participants, may be put to use. Another set of financial regulations to reduce the volatility is to increase transaction costs and margin requirements in the hope of restraining noise-trading behaviour. The results in Japan, Poland, the Czech Republic, Hungary, Estonia and India show that there is no bidirectional volatility spillover between stock return and industrial production. Nonetheless, there is some evidence of a volatility 
spillover from the real economy to financial markets in both Italy and Slovak Republic. However, this finding may be explained by Chen and Ross (1986), who noted that stock returns were exposed to systematic risks related to the spread between long and short interest rates, inflation, and industrial production, so they were priced according to the news regarding these variables.

\section{Conclusion}

This study used the quantile regression and volatility spillover tests to examine the relationships between stock prices and industrial production for 19 OECD economies over a 20 -year period. The results of the quantile regressions emphasize that the effect of stock markets on economic activity tends to vary with the level of industrial production. The effect of the stock market on economic growth is significant across quantiles only in the cases of Japan and Estonia. These findings are consistent with the view that the capital market may be able to promote growth. In addition, the dependence between the real economy and the stock market is positive and exists only in the higher quantiles for Poland, Turkey, Russia, the UK and France. Therefore, these countries do not benefit from the stock market when they most need it, such as when an economic contraction begins to appear. Meanwhile, the results reveal that the dependence between the stock performance and the industrial production is significant in lower quantiles for Spain, Italy, Germany, Slovak Republic, Slovenia, Brazil and Hungary. This result indicates that the stock market can stimulate economic recovery during production decreases. Based on the data for Greece, it is impossible to consider that the changes in real activity are related to stock prices. Thus, stock market information cannot be used for development policies. Stock return facilitates economic growth only at moderate levels for Belgium and the Czech Republic. This result suggests that the financial sector and the real sector are interrelated with each other in stable times. The results obtained for the USA reveal that the effect of the stock market on industrial production exhibits asymmetric features with a negative degree of impact in the lowest quantile and a positive impact in the highest quantile. It may be interpreted that the stock market acts as a catalyst in the USA: when the economy begins to slow down, the stock market accelerates the economic collapse; then, production growth begins to appear, and the stock market warms up the economic activity. The stock market has a restricted ability to affect industrial production for OECD countries except Japan and Estonia. Our results from the volatility spillover tests suggest that volatility in stock prices has no predictive power for economic growth in the cases of Japan, Poland, the Czech Republic, Hungary, Estonia and India. However, most of the evidence appears to favour the view that the relationship between stock market volatility and economic growth volatility is bidirectional. Financial reform can be proposed to attenuate stock price volatility 
for countries that must avoid the spillover effect of the stock market. Economic regulators will resort to financial policies, which cover circuit breakers, sunshine trading, transaction costs and margin requirements, to stabilize equity prices in providing liquidity to the stock market. Overall, the results confirm that the response of capital markets to economic growth depends more on the state of the economy than the state of the country's development.

\section{Appendix 1}

\section{Time-varying effect of the stock market on industrial production}

This appendix is prepared to analyse the evolution of the effect of the stock market on industrial production over time in OECD countries. To this end, the Multivariate GARCH model is used to detect the stability of beta coefficients. To visualize the findings, the HP filter proposed by Hodrick and Prescott (1997) is applied to the beta series to better determine the long-term trends between stock return and economic growth. In this way, difference in both the length and the magnitude of the cycles are expected to show clearly. Shaded areas in charts represent the 2008 global (June 2007-April 2009) and euro zone crisis (November 2009-September 2012), respectively.

The multivariate GARCH model can be used to obtain the time-varying $\beta$ between stock return and growth rate. Consider that $x_{t}$ refers to the return of the stock market and $y_{t}$ refers to the growth rate of industrial production. According to statistical theory (Tsay, 2014:251-257):

$$
\begin{aligned}
& \operatorname{Var}=\left(x_{t}+y_{t}\right)=\operatorname{Var}\left(x_{t}\right)+2 \operatorname{Cov}\left(x_{t}, y_{t}\right)+\operatorname{Var}\left(y_{t}\right), \\
& \operatorname{Var}=\left(x_{t}-y_{t}\right)=\operatorname{Var}\left(x_{t}\right)-2 \operatorname{Cov}\left(x_{t}, y_{t}\right)+\operatorname{Var}\left(y_{t}\right), \\
& \operatorname{Cov}\left(x_{t}, y_{t}\right)=\frac{\operatorname{Var}\left(x_{t}+y_{t}\right)-\operatorname{Var}\left(x_{t}-y_{t}\right)}{4} .
\end{aligned}
$$

Time-varying covariance between $x_{t}$ and $y_{t}$ can be calculated using the volatilities of $x_{t}+y_{t}, x_{t}-y_{t}$. Let $\sigma_{x+y, t}, \sigma_{x-y, t}, \sigma_{x, t}, \sigma_{y, t}$ denote the volatility of $x_{t}+y_{t}, x_{t}-y_{t}, x_{t}$ and $y_{t}$, respectively. Using the identity in the formula $\operatorname{Cov}\left(x_{t}, y_{t}\right)$, time-varying betas can be obtained using the following equation:

$$
\beta_{t}=\frac{\sigma_{x+y, t}^{2}+\sigma_{x-y, t}^{2}}{4 \sigma_{x, t} \sigma_{y, t}} .
$$

The HP filter is a kind of data-smoothing technique for removing short-term movements in the cycle literature. Thereby, the method enables revelation of long-term trends (Ravn and Uhlig, 2002). 
The Hodrick-Prescott filter extracts the long-run trend of $y_{t}$ by minimizing the following function:

$$
\sum_{t=1}^{T}\left(y_{t}-s_{t}\right)^{2}+\lambda \sum_{t=2}^{T-1}\left(\left(s_{t+1}-s_{t}\right)-\left(s_{t}-s_{t-1}\right)\right)^{2} .
$$

The first part of the minimization refers to squared deviations from the trend, while the second part is the penalty for the variations in the growth rate of the trend component. Technically, the penalty parameter $\lambda$ provides the smoothness of the adjusted trend series. For monthly data we use $\lambda=14,400$ as suggested by Ravn and Uhlig (2002).

Table 5: Time-varying beta estimates for countries

\begin{tabular}{|c|c|c|c|}
\hline Country & Period date & Low beta & High beta \\
\hline Belgium & $1989-12$ / 2016-07 & -0.235 & 0.747 \\
\hline Brazil & $1989-12$ / 2016-07 & -0.557 & 0.449 \\
\hline Czech Republic & 1994-01 / 2016-07 & -0.283 & 0.285 \\
\hline Estonia & 1998-01 / 2016-07 & -0.310 & 0.692 \\
\hline France & $1989-12$ / 2016-07 & -0.097 & 0.246 \\
\hline Germany & $1989-12$ / 2016-07 & -0.293 & 0.641 \\
\hline Greece & $1989-12$ / 2016-07 & -0.185 & 0.209 \\
\hline Hungary & 1991-01 / 2016-07 & -0.287 & 0.535 \\
\hline India & 1994-04 / 2016-07 & -0.075 & 0.322 \\
\hline Italy & $1989-12$ / 2016-07 & -0.081 & 0.267 \\
\hline Japan & $1989-12$ / 2016-07 & -0.158 & 0.586 \\
\hline Poland & $1991-05$ / 2016-07 & -0.230 & 0.313 \\
\hline Russia & 1997-09 / 2016-07 & -0.177 & 0.208 \\
\hline Slovak Republic & 1993-09 / 2016-07 & -1.444 & 1.207 \\
\hline Slovenia & $1994-06$ / 2016-07 & -0.268 & 0.521 \\
\hline Spain & 1989-12 / 2016-07 & -0.106 & 0.247 \\
\hline Turkey & 1989-12 / 2016-07 & -0.665 & 1.889 \\
\hline UK & $1989-12$ / 2016-07 & -0.106 & 0.273 \\
\hline USA & $1989-12$ / 2016-07 & -0.184 & 0.318 \\
\hline
\end{tabular}

Source: Author's calculations. 
Belgium

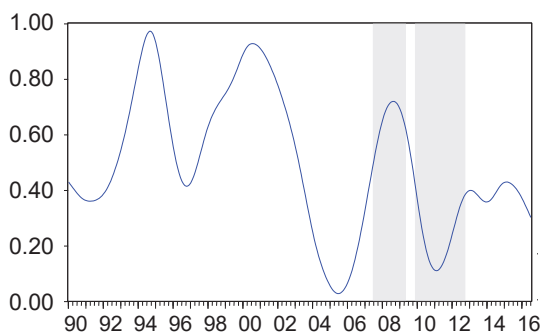

Czech Republic

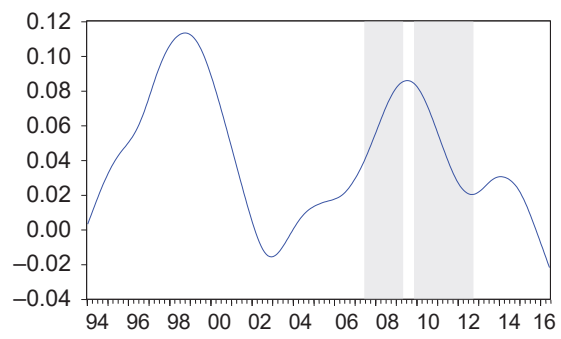

France

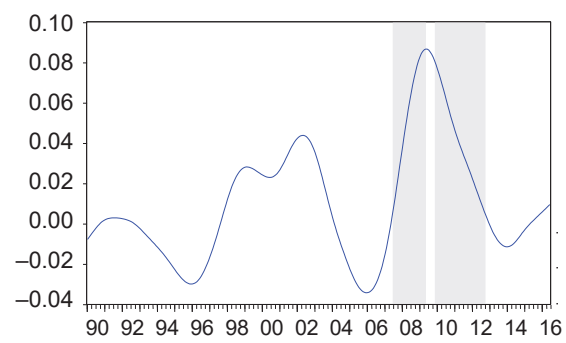

Greece

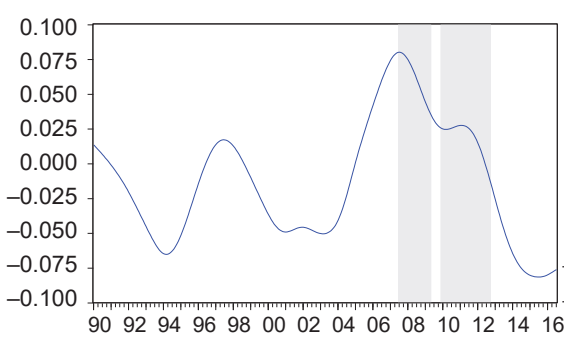

Brazil

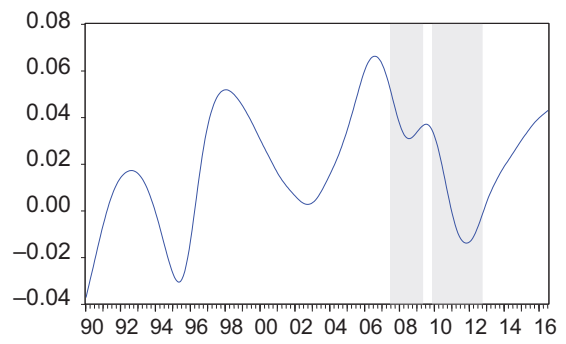

Estonia

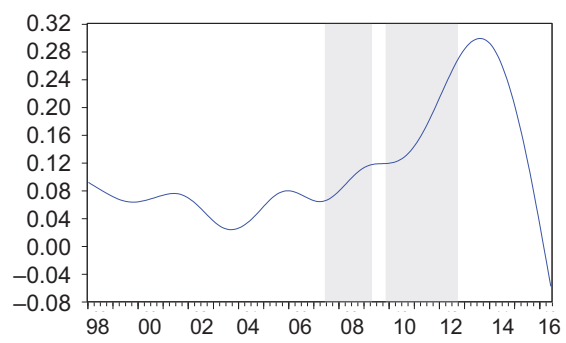

Germany

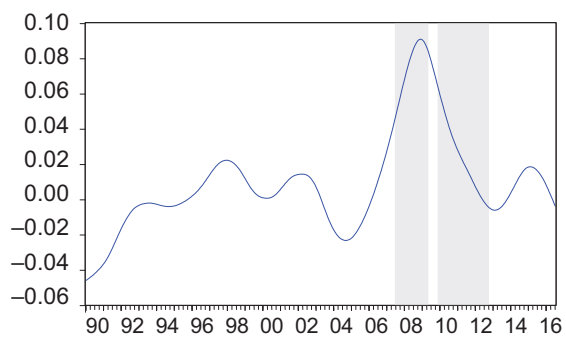

Hungary

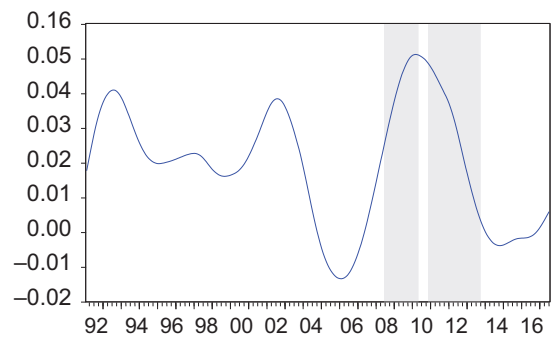


Figure 1: (Continuation)
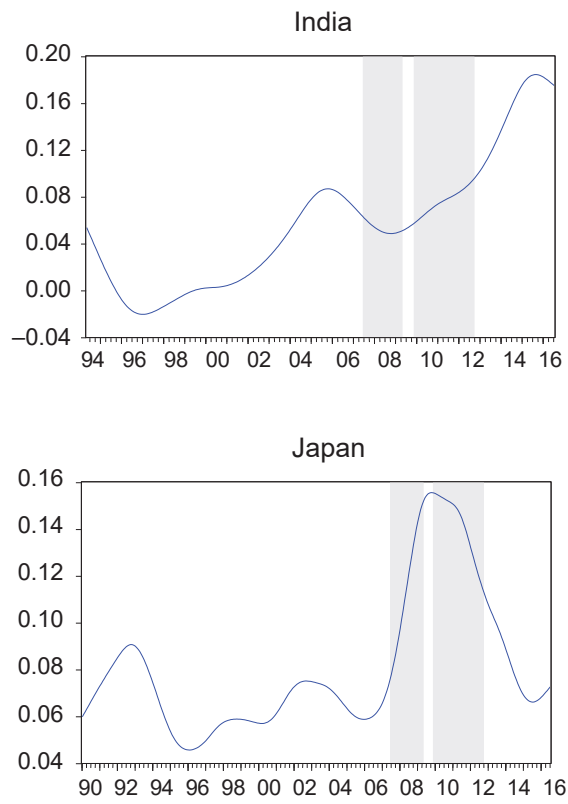

Russia

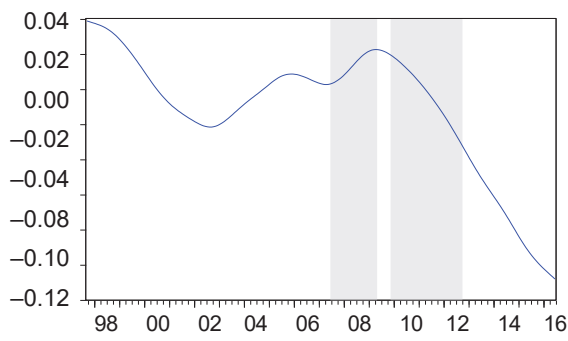

Slovenia

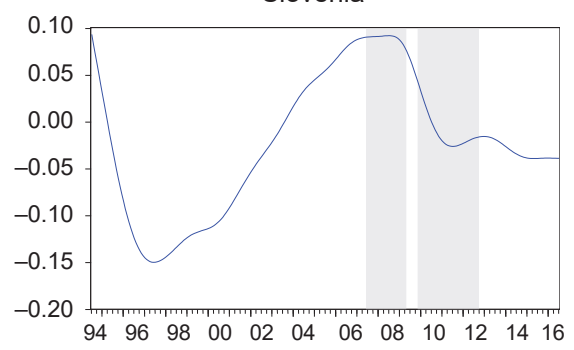

Italy

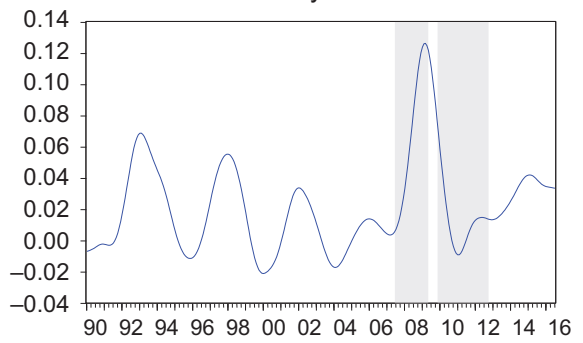

Poalnd

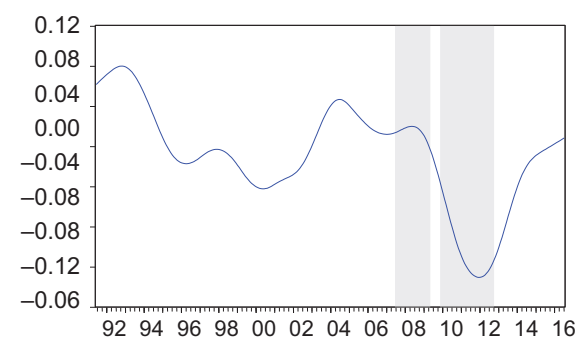

Slovakia

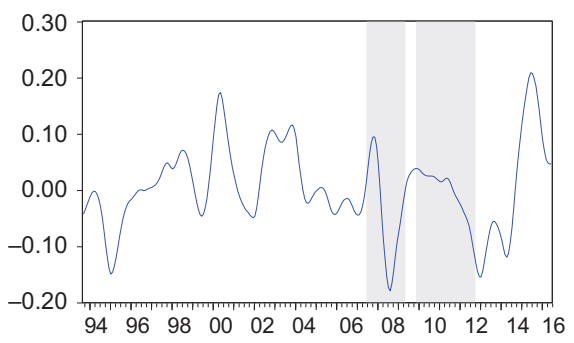

Spain

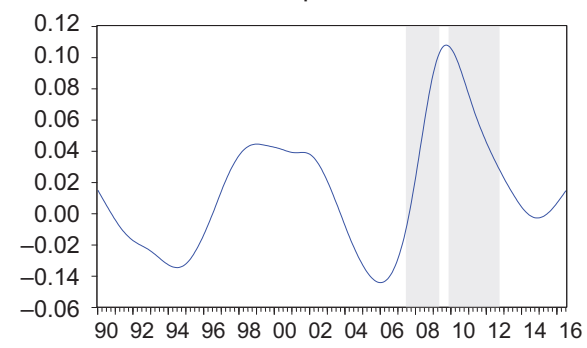



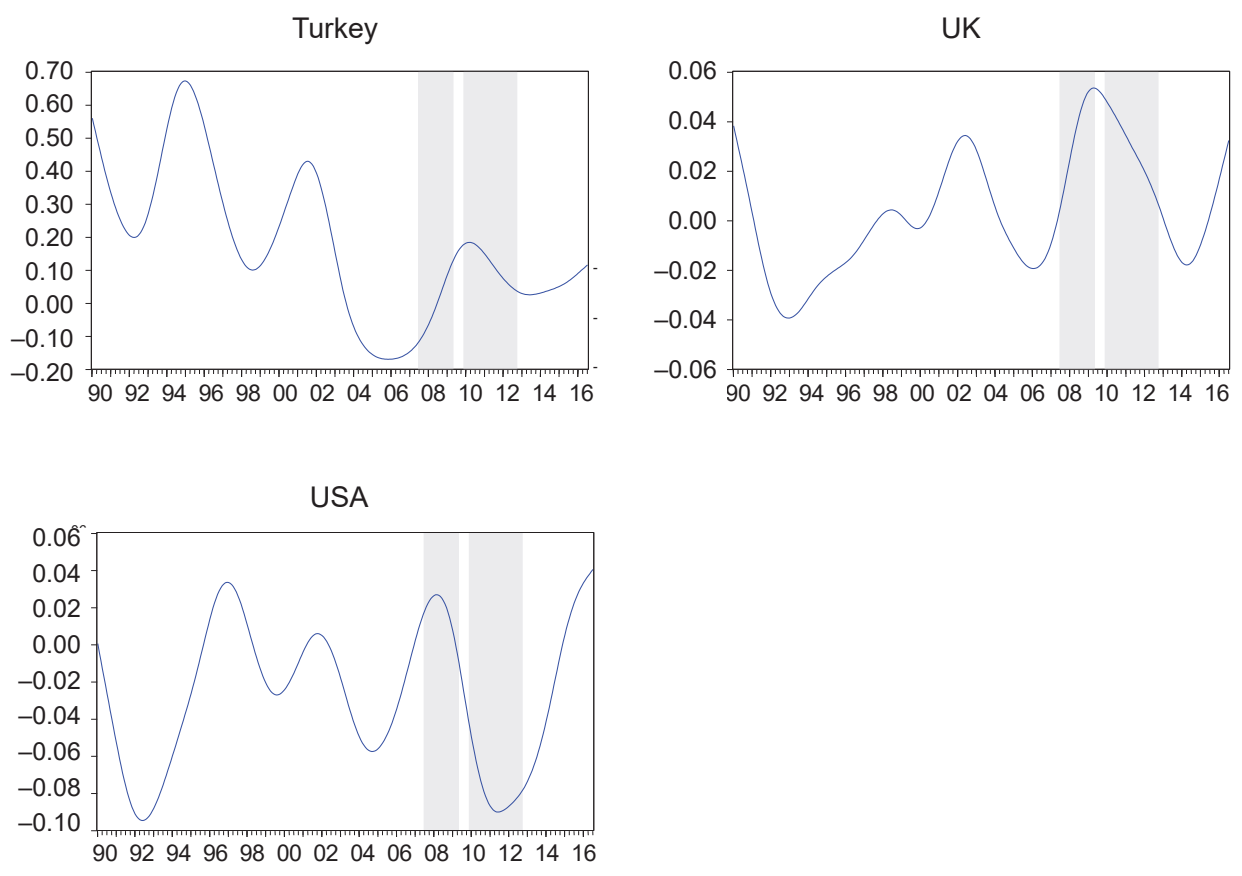

Source: Author's calculations.

Belgium exhibits several cycles of the same magnitude between 1990 and 2000. After 2000 , the downward trend is clearly seen until 2006. However, the trend reverses after that and reaches its peak point in the 2008 global crisis. Then the variability in the cycles takes place in smaller dimensions, which indicates a weaker linkage in terms of the financegrowth nexus. The cycles in Brazil can be characterized by their large variability covering the period 1990-2014. However, compared to previous years, the Brazilian economy has become more dependent on the stock market since 2013. It is evident that the Czech Republic has two financial cycles and their lengths are eight years. The cycles have occurred in 1994-2002 and in 2004-2012. On the other hand, the impact of the stock market on economic growth has begun to weaken since 2010. The synchronization of the real and the financial sectors in Estonia has increased substantially since 2003. The peak of the financial cycle tended to coincide with episodes of the end of the euro zone crisis. Then, the relationship suddenly began to decline so that it curtailed the degree of comovement across the markets. France shows a low concordance in the finance-growth 
nexus. After 2012, stock prices tend to move away from industrial production. The financial cycle in 2008-2012 was comparably big and ended with the euro zone crisis. The economic and finance link in Germany exhibits shorter fluctuations but higher frequency until the end of 2009. Cycles observed in frequent and short periods are caused by volatility of the financial market. Germany also experienced boom-bust cycles between the global and euro zone crises. In the case of Greece, the positive concordance across the equity and real markets has intensified only during the global crisis. With the beginning of the euro zone crisis, the contribution of the stock market to the economy began to decrease. Hungary already has a high level of stability in terms of cycles in the period 1990-2002. Although the period 2003-2006 presented a little negative concordance, Hungary made good progress towards 2010. Unfortunately, the same level has never been seen again after 2010 and the synchronization has been steadily decreasing. For Japan, interdependencies between the stock market and industrial production seem to increase until the end of 2010. Surprisingly, a decoupling between the real and financial markets has been observed in the years following 2010. India has succeeded in making the financial and real markets more synchronized in all the periods. The real economy is now much more dependent on the stock market development compared to the past two decades in India. The cycles in Italy are more volatile in the period 1990-2007 than in the period 2008-2016. During the first period, a phase of recession was followed by a phase of expansion. The cycle in Italy tends to upswing before the onset of the 2009 euro zone financial crisis. The cycle suggests that crises exercise a significant influence on the linkages between the stock market and the economy. For Poland, the economic growth and the equity price cycle display a low level of synchronicity until the end of the 2008 crisis. At the same time, the comovement disappeared with the beginning of the euro zone crisis. Henceforth, industrial production is unrelated to stock prices. The lesser synchronization of Russia continued until the first half of 2010. In addition, the year 2011 corresponds to turning points where the stock markets and industrial relationship is broken. The decoupling of stock markets from economic fundamentals is probably due to the fact that Russia's economy is heavily dependent on oil revenues. For Slovak Republic, the impact of stock price movements on economic activity is subject to abrupt changes associated with the duration of phases. Furthermore, cycles seem to be more volatile and shorter than in other OECD countries. Slovak Republic has eight cycles, whose completion from full peak to trough may last less than two years. This finding implies that it is very difficult to make an appropriate design of macro prudential policy. In the case of Slovenia, troughs and peaks are alternating in the whole sample. The minimum duration of a cycle is not less than six years. Over the periods 1995-2003 and 2011-2016, the stock market and the economy are not integrated very well. Interestingly, the peak of the 2004-2010 cycle is more associated 
with the onset of the 2008 financial crisis. Both growth rates and stock prices tend to pick up simultaneously. The cycle dispersion in Spain tends to be irregular in terms of both magnitude and length. Nevertheless, the peak of a cycle is at the end of 2009. It can be seen that a cycle based on industrial production and stock return moves towards the trough during the post-2010 period. An obvious deceleration in the cycles covering the period 1990-2008 can be seen in the case of Turkey. Moreover, cycles reach peaks around 1994 and 2000; these dates nearly correspond to the 1994 currency crisis and the 2001 banking crisis in Turkey. Similarly, since post-2000s, the stock market and output co-movement have weakened from year to year. From the UK chart, it emerges that the dynamic behaviour of the impact of the stock market on economic growth displays a fairly irregular cycle during the period 1990-2016. The weakest link between finance and economy is prevalent until the post-1990s period. While the greatest cycle in terms of magnitude occurred between 2008 and 2012, the peak corresponded to the euro zone crisis period. In the case of the USA, stock market and economic activity interactions start to trend down before the mid-1990s. The USA experienced smaller magnitudes of the cycles covering the period 1994-2007. While one cycle reaches the trough during the dotcom bubble of the late 1990s, the other one reaches the peak during the 2008 crisis. The economic growth becomes less sensitive to financial development in the wake of the euro zone crisis of 2009.

The main findings of the appendix are that the Czech Republic, Germany, France, Hungary, Japan, Italy, Spain and the UK exhibited financial cycles that peaked around the euro zone crisis. The peak of the cycles in Belgium, Estonia, Greece, Slovenia and the USA become more evident during the 2008 global crisis. The results imply that real economy and the stock market are highly correlated during crisis times and diverge in other periods. This fact may stem from the fact that both industrial production and stock market drop together in crisis periods. In the recent years, a decoupling between economy and finance is observed in the context of Turkey, Russia and Poland. This means that these countries will not be able to benefit from capital markets in the coming period. The effects of common monetary policy, currency unions and market size on the link between finance and economy deserve further research.

\section{References}

Ahn, E. S., Lee, J. M. (2006). Volatility Relationship between Stock Performance and Real Output. Applied Financial Economics, 16(11), 777-784, http://doi. org/10.1080/09603100500424775

Arestis, P., Demetriades, P. O., Luintel, K. B. (2001). Financial Development and Economic Growth: The Role of Stock Markets. Journal of Money, Credit and Banking, 33(1), 16-41, https://doi.org/10.2307/2673870 
Atje, R., Jovanovic, B. (1993). Stock Markets and Development. European Economic Review, 37(2-3), 632-640, https://doi.org/10.1016/0014-2921(93)90053-D

Bekaert, G., Harvey, C. R. (1998). Capital Markets: An Engine for Economic Growth. The Brown Journal of World Affairs, 5(1), 33-53.

Bencivenga, V. R., Smith, B. D., Starr, R. M. (1996). Equity Markets, Transactions Costs, and Capital Accumulation: An Illustration. The World Bank Economic Review, 10(2), 241-265, https://doi.org/10.1093/wber/10.2.241

Binswanger, M. (2004). Stock Returns and Real Activity in The G-7 Countries: Did The Relationship Change During The 1980s? The Quarterly Review of Economics and Finance, 44(2), 237-252, https://doi.org/10.1016/j.qref.2003.07.001

Caporale, G. M., Spagnolo, N. (2003). Asset Prices and Output Growth Volatility: The Effects of Financial Crises. Economics Letters, 79(1), 69-74, https://doi.org/10.1016/ S0165-1765(02)00289-6

Chen, N. F., Roll, R., Ross, S. A. (1986). Economic Forces and the Stock Market. Journal of Business, 59(3), 383-403.

Colombage, S. R. (2009). Financial Markets and Economic Performances: Empirical Evidence from Five Industrialized Economies. Research in International Business and Finance, 23(3), 339-348, https://doi.org/10.1016/j.ribaf.2008.12.002

Cooray, A. (2010). Do Stock Markets lead To Economic Growth? Journal of Policy Modeling, 32(4), 448-460, https://doi.org/10.1016/j.jpolmod.2010.05.001

Dawson, P. J. (2003). Financial Development and Growth in Economies in Transition. Applied Economics Letters, 10(13), 833-836, http://doi.org/10.1080/1350485032000154243

Demetriades, P. O., Hussein, K. A. (1996). Does Financial Development Cause Economic Growth? Time-Series Evidence from 16 Countries. Journal of development Economics, 51(2), 387-411, https://doi.org/10.1016/S0304-3878(96)00421-X

Demirgüç-Kunt, A., Levine, R. (1996). Stock Markets, Corporate Finance, and Economic Growth: An Overview. The World Bank Economic Review, 10(2), 223-239, https://doi. org/10.1093/wber/10.2.223

Duca, G. (2007). The Relationship between the Stock Market and the Economy: Experience from International Financial Markets. Bank of Valletta Review, 36(3), 1-12.

Fama, E. F. (1990). Stock Returns, Expected Returns, and Real Activity. The Journal of Finance, 45(4), 1089-1108, https://doi.org/10.1111/j.1540-6261.1990.tb02428.x

Fischer, S., Merton, R. (1984). Macroeconomics and Finance: The Role of the Stock Market. Carnegie-Rochester Conference Series on Public Policy, 21, 57-108, https://doi. org/10.1016/0167-2231(84)90005-8

Greenwood, J., Jovanovic, B. (1990). Financial Development, Growth, and the Distribution of Income. Journal of Political Economy, 98(5), 1076-1107, https://doi. org/10.1086/261720

Guo, J. (2015). Causal Relationship between Stock Returns and Real Economic Growth in the Pre-And Post-Crisis Period: Evidence from China. Applied Economics, 47(1), 12-31, http://doi.org/10.1080/00036846.2014.959653 
Hafner, C. M., Herwartz, H. (2006). A Lagrange Multiplier Test for Causality in Variance. Economics Letters, 93(1), 137-141, https://doi.org/10.1016/j.econlet.2006.04.008

Handa, J., Khan, S. R. (2008). Financial Development and Economic Growth: A Symbiotic Relationship. Applied Financial Economics, 18(13), 1033-1049, http://doi. org/10.1080/09603100701477275

Harris, R. D. (1997). Stock Markets and Development: A re-assessment. European Economic Review, 41(1), 139-146, https://doi.org/10.1016/S0014-2921(96)00021-9

Hodrick, R. J., Prescott, E. C. (1997). Postwar US Business Cycles: an Empirical Investigation. Journal of Money, credit, and Banking, 29(1), 1-16, https://doi.org/10.2307/2953682

Keynes, J. M. (1936). The General Theory of Employment, Interest and Money. London: Macmillan.

Kim, S., In, F. H. (2003). The Relationship between Financial Variables and Real Economic Activity: Evidence from Spectral and Wavelet Analyses. Studies in Nonlinear Dynamics \& Econometrics, 7(4), https://doi.org/10.2202/1558-3708.1183

Koenker, R., Bassett Jr, G. (1978). Regression Quantiles. Econometrica. Journal of the Econometric Society, 46(1), 33-50, https://doi.org/10.2307/1913643

Kupiec, P. (1991). Stock Market Volatility in OECD Countries: Recent Trends, Consequences for the Real Economy and Proposals for Reform. Economic Studies, (17).

Levine, R. (1991). Stock Markets, Growth, and Tax Policy. The Journal of Finance, 46(4), 14451465, https://doi.org/10.1111/j.1540-6261.1991.tb04625.x

Levine, R. (1997). Financial Development and Economic Growth: Views and Agenda. Journal of Economic Literature, 35(2), 688-726.

Mankiw, N. G., Romer, D., Weil, D. N. (1992). A Contribution to the Empirics of Economic Growth. The Quarterly Journal of Economics, 107(2), 407-437, https://doi. org/10.2307/2118477

Mauro, P. (2003). Stock Returns and Output Growth in Emerging and Advanced Economies. Journal of Development Economics, 71(1), 129-153, https://doi.org/10.1016/ S0304-3878(02)00136-0

Morck, R., Shleifer, A., Vishny, R. W. (1990). Do Managerial Objectives Drive Bad Acquisitions? The Journal of Finance, 45(1), 31-48, https://doi.org /10.1111/j.1540-6261. 1990. tb05079.x

Naifar, N. (2016). Do Global Risk Factors and Macroeconomic Conditions Affect Global Islamic Index Dynamics? A Quantile Regression Approach. The Quarterly Review of Economics and Finance, 61, 29-39, https://doi.org/10.1016/j.qref.2015.10.004

Nourzad, F. (2002). Financial Development and Productive Efficiency: A Panel Study of Developed and Developing Countries. Journal of Economics and Finance, 26(2), 138-148, https://doi.org/10.1007/BF02755981

Pearce, D. K. (1983). Stock Prices and the Economy. Federal Reserve Bank of Kansas City Economic Review, 68(9), 7-22. 
Pilinkus, D. (2010). Macroeconomic Indicators and Their Impact on Stock Market Performance in the Short and Long Run: The Case of the Baltic States. Technological and Economic Development of Economy, 16(2), 291-304, http://doi.org/10.3846/tede.2010.19

Ram, R. (1999). Financial Development and Economic Growth: Additional Evidence. Journal of Development Studies, 35(4), 164-174, http://doi.org/10.1080/00220389908422585

Ravn, M. O., Uhlig, H. (2002). On Adjusting the Hodrick-Prescott Filter for the Frequency of Observations. The Review of Economics and Statistics, 84(2), 371-376, http://doi. org/10.1162/003465302317411604

Rousseau, P. L., Wachtel, P. (2000). Equity Markets and Growth: Cross-Country Evidence on Timing and Outcomes, 1980-1995. Journal of Banking \& Finance, 24(12), 1933-1957, https://doi.org/10.1016/S0378-4266(99)00123-5

Schwert, G. W. (1989). Why Does Stock Market Volatility Change Over Time? The Journal of Finance, 44(5), https://doi.org/ 1115-1153. 10.1111/j.1540-6261. 1989.tb02647.x

Shiller, R. J. (1990). Speculative Prices and Popular Models. The Journal of Economic Perspectives, 4(2), 55-65, https://doi.org/10.1257/jep.4.2.55

Singh, A. (1999). Should Africa Promote Stock Market Capitalism? Journal of International Development, 11(3), 343-365, https://doi.org/10.1002/ (sici)1099-1328(199905/06)11:3<343::aid-jid593>3.0.co;2-q

Stiglitz, J. E., Weiss, A. (1983). Incentive Effects of Terminations: Applications to the Credit and Labor Markets. The American Economic Review, 73(5), 912-927.

Tang, D. (2006). The Effect of Financial Development on Economic Growth: Evidence from the APEC Countries, 1981-2000. Applied Economics, 38(16), 1889-1904, http://doi. org/10.1080/00036840500427239

Teng, K. T., Yen, S. H., Chua, S. Y., Lean, H. H. (2016). Time-Varying Linkages of Economic Activities in China and the Stock Markets in ASEAN-5. Contemporary Economics, 10(2), 137-152, https://doi.org/10.5709/ce.1897-9254.205

Tsay, R. S. (2014). An Introduction to Analysis of Financial Data with R. John Wiley \& Sons.

Van Nieuwerburgh, S., Buelens, F., Cuyvers, L. (2006). Stock Market Development and Economic Growth in Belgium. Explorations in Economic History, 43(1), 13-38, https://doi. org/10.1016/j.eeh.2005.06.002

Wachtel, P. (2001). Growth and Finance: What Do We Know and How Do We Know It? International Finance, 4(3), 335-362, https://doi.org/10.1111/1468-2362.00077 